\section{З. ЕКОНОИКАА ПРИРОДОКОРИСТУВАННЯ}

Доц. А.А. Теребух, д-р екон. наук; доц. Г.Я. Ільницька-Гикавчук, канд. екон. наук доц. О.П. Макар, канд. екон. наук-НУ"Львівська політехніка"

\section{УДОСКОНАЛЕННЯ УПРАВЛІННЯ БІЗНЕС-ПРОЦЕСАМИ} НА ПІДПРИЄМСТВАХ УКРАЇНИ

Розглянуто та проаналізовано сутність управління на основі бізнес-процесів, переваги підприємств від його впровадження. Встановлено, що сучасний стан розвитку економіки характеризується низькою інноваційною активністю, тому необхідно перепроектувати бізнес-процеси на підприємствах. Виділено такі види бізнес-процесів: основні, забезпечувальні, управління та розвитку. Проведено класифікацію методів удосконалення управління бізнес-процесами, зокрема виділено такі методи як: реінжиніринг, перепроектування, бенчмаркінг, аналіз робочих осередків, ідеалізація.

Ключові слова: бізнес-процес, управління, підприємство, вузьке місце, реінжиніринг, перепроектування, бенчмаркінг.

Постановка проблеми. Світовий досвід показує, що сучасний динамічний розвиток ринку товарів і послуг, зростання конкуренції, низький обсяг проведення інновацій на підприємствах, що призводить до зниження конкурентоспроможності продукції та появи бар'єрів у міжнародній торгівлі, сировинно орієнтації експорту, зумовлюють потребу пошуку нових інструментів і методів управління виробничими процесами. Все це зумовило актуальність проведених досліджень

Аналіз останніх досліджень та публікацій з проблеми. Основні проблеми управління бізнес-процесами висвітлено у наукових роботах сучасних вітчизняних і зарубіжних учених, зокрема: Б. Андерсена, О. Данченко Г., Калянова, О. Полінкевич, В. Пономаренко М., Робсона, Л. Таранюк, В. Тупкала М. Фентона, М. Хаммера, Дж. Чампі, А. Шеєра та ін. Проте проблема удосконалення бізнес-процесів на підприємствах шкіряного виробництва є недостатньо розкрита та потребує подальшого дослідження.

Мета роботи полягає в аналізі сутності бізнес-процесів та процесного підходу управління, групування методів удосконалення бізнес-процесів, аналіз інноваційної активності економіки України.

Виклад основного матеріалу. Сучасний стан розвитку економіки характеризується низькою інноваційною активністю. Так, в Україні лише кожне шосте підприємство здійснює інноваційну діяльність, тоді як у розвинених країнах (США, Японія) - 70 \% від загальної кількості підприємств. Яскравим відображенням стану інноваційного розвитку підприємств України є 82 позиція зі 133 (за даними 2012 р.) у міжнародному рейтингу World Economic Forum за індексом глобальної конкурентоспроможності економіки, який враховує технологічний рівень та інноваційний потенціал країни [1].

Так, питома вага підприємств України, які займалися інноваціями, становила лише 16,8 \% у 2013 р., а які впроваджували інновації - 13,6 \%, питома вага реалізованої інноваційної продукції - лише 3,3\% від загального обсягу промислової [2]. Інновації переважно здійснюють власними коштами підприємства, що не завжди є позитивно, оскільки не завжди підприємства їх мають [2]. Також необхідно зазначити, що промислові підприємства здебільшого економічно не зацікавлені у їх впровадженні, оскільки це дорогий процес.

Інноваційна діяльність промислових підприємств України за 2009-2013 рр. фінансувалася за рахунок коштів із різних джерел - власних, державного бюджету, іноземних інвесторів та інших джерел, для порівняння їх співвідношення, суми цих витрат наведено у табл.

Табл. Джерела фінансування інноваційної діяльності промислових підприємсте

\begin{tabular}{|c|c|c|c|c|c|c|}
\hline & & Укранни & & 30 & & \\
\hline \multirow{2}{*}{ Рік } & \multirow{2}{*}{$\begin{array}{c}\text { Загальна } \\
\text { сума витрат }\end{array}$} & \multirow{2}{*}{$\begin{array}{c}\text { Темп } \\
\text { приросту, \% }\end{array}$} & \multicolumn{4}{|c|}{ Зокрема за рахунок коштів } \\
\hline & & & власних & $\begin{array}{c}\text { державного } \\
\text { бюджету }\end{array}$ & $\begin{array}{l}\text { іноземних } \\
\text { інвесторів }\end{array}$ & $\begin{array}{c}\text { інші } \\
\text { джерела }\end{array}$ \\
\hline 2009 & 7949,9 & $\overline{-}$ & $\overline{516}$ & 127 & 1512,9 & 1140,6 \\
\hline 2010 & 8045,5 & 1,2 & 4775,2 & 87 & 2411,4 & 771,9 \\
\hline 2011 & 14333,9 & 80,3 & 7585,6 & 149,2 & 56,9 & 6542,2 \\
\hline 2012 & 11480,6 & 44,4 & 7335,9 & 224,3 & 994,8 & 2925,6 \\
\hline 2013 & 9562,6 & 20,3 & 6973,4 & 24,7 & 1253,2 & 1311,3 \\
\hline
\end{tabular}

Згідно з табл., в Україні спостерігається тенденція до збільшення обсягів джерел фінансування, зокрема найбільшу частку становлять власні джерела, які характеризуються зростанням (34,9\%), та кошти іноземних інвесторів - їх частка повільно спадає $(-17,17 \%)$. Так, загальна сума витрат у звітному періоді збільшилась порівняно з 2009 р., темп приросту суми витрат у 2013 р., порівняно з 2009 р., становить 20,3\%. Певною мірою такий стан можна пояснити нестабільним нормативно-правовим середовищем функціонування підприємств, що не приваблює іноземних інвесторів.

Основні фонди підприємств є значно зношені, що призводить до зростання собівартості продукції та зниження і1ї конкурентоспроможності. Тому постає потреба активізувати перепроектування бізнес-процесів технічного оснащення виробництва. Використання цього підходу в управлінні підприємством передбачає глибше розуміння поняття "бізнес-процесу". У широкому розумінні під бізнес-процесом розуміють структуровану послідовність дій із виконання відповідного виду діяльності на всіх етапах життєвого циклу предмета діяльності [3]. Бізнес-проиес - це сукупність різних видів діяльності, в межах якої на вході використовується один або кілька ресурсів, а внаслідок цієї діяльності на виході створюється продукт, що має цінність для споживача [4].

Одним із початкових етапів переходу підприємства на засади процесного управління є класифікація бізнес-процесів для наступного виділення на ії основі складу окремих бізнес-процесів, які характерні підприємствам того сектору економіки, який досліджується. Тому усі бізнес-процеси, які відбуваються, $є$ неоднорідними та мають свої притаманні особливості, залежно від специфікації діяльності кожного підприємства. Потрібно виділити такі їх види:

1) основні бізнес-процеси (виробництво, збут продукції, маркетингова діяльність); 
2) забезпечувальні бізнес-процеси (здійснює підтримку інфраструктури та основних процесів);

3) бізнес-процеси управління (охоплюють управління фінансовою стійкістю, трудовою діяльністю, активами підприємства та ін.);

4) бізнес-процеси розвитку (охоплюють впровадження інноваційних технологій, інвестиційних проектів тощо) [1].

Для вітчизняних організацій є дуже значущим розроблення певної покрокової схеми системи управління для реалізації процесного підходу, а потім впровадження методів удосконалювання, які будуть потребувати значних трансформацій в управлінні. Управління бізнес-процесами - сукупність методів і засобів впливу суб'єктів управління підприємства шляхом планування, організовування, мотивування та контролювання на розроблення продуктів, маркетинг збут, постачання, виробництво, сервіс, доставку, забезпечення з метою задоволення вимог клієнтів та підвищення ефективності господарювання підприємства [4]. Упровадження процесно-орієнтованого управління може надати такі переваги для підприємств [1]:

- управління бізнес-процесами середньою ланкою менеджменту;

- зниження значення функціонального управління, де кожний структурний підрозділ слідкує лише за своїми процесами;

- розширення контролю за рухом бізнес-процесів від управління матеріальними ресурсами до збуту продукції, підвищення відповідальності структурних підрозділів за бізнес-процесами;

- визначення проблемних місць під час реалізації бізнес-процесів, встановлення винних, швидке усунення "вузьких місць";

- надання повноважень підрозділам з управління бізнес-процесами в рамках їх компетенції, що посилює відповідальність менеджерів процесів.

Для вітчизняних підприємств є дуже значущим впровадження методів удосконалювання, які будуть потребувати значних трансформацій в управлінні, зокрема різні методи вдосконалення бізнес-процесів, які поділяють на короткота довготермінові (рис.).

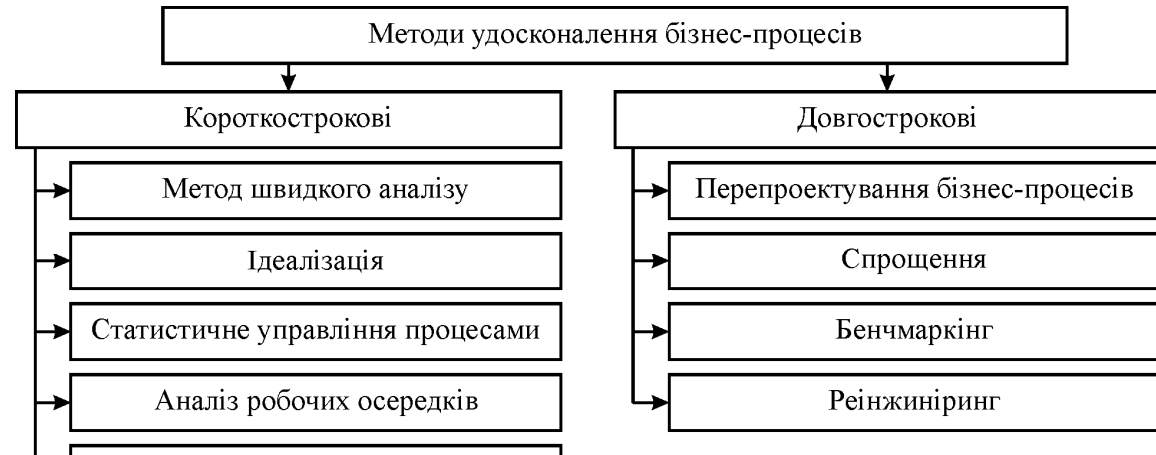

Метод структуризації функцій якості

Рис. Методи удосконалення бізнес-процесів [5]

Методика швидкого аналізу грунтується на виявленні й аналізі можливих варіантів рішень для виділених проблемних ділянок виробництва; методика ідеалізації бізнес-процесів грунтується на методі побудови ідеальної системи, яка полягає в бажанні виконувати ідеальні бізнес-процеси; статистичного управління бізнес-процесами є виокремлення чинників, що впливають на його ефективність; метод структуризації функції якості дає змогу встановити зв'язки між вимогами і прийомами їх задоволення; метод аналізу робочих осередків полягає у визначенні технічних вимог для продукту чи послуги, які необхідні для споживача.

До довготермінових методів удосконалень належать: перепроектування бізнес-процесів, тобто методика покращення, що заснована на чіткому подетальному аналізі існуючих вже бізнес-процесів та передбачає можливість виправлення існуючого процесу до цілей підприємства; бенчмаркінг - удосконалення, яке спрямоване на пошук та оцінку найкращих прикладів ведення бізнесу існуючими конкурентами.

Реінжиніринг - це фундаментальне переосмислення і радикальне перепроектування бізнес-процесів для досягнення істотних покращень у ключових показниках результативності, таких як витрати, якість, обслуговування і швидкість. Використання цього підходу дає змогу подивитися на мету бізнес-процесу по-новому, повністю ігноруючи існуючий бізнес-процес і структуру підприємства.

Висновки. Системи управління, які діють на більшості підприємствах, вже давно не відповідають сучасним вимогам динамічного ринкового середовища, який постійно змінюється внаслідок адаптації до всезростаючих потреб споживачів та відносно конкурентів. Раціональне управління бізнес-процесами дають змогу реалізовувати встановлені стратегічні цілі, що підвищить економічну ефективність виробництва та конкурентоспроможність продукції.

\section{Література}

1. Таранюк Л.М. Реінжиніринг бізнес-процесів промислових підприємств: теорія, методологія, практика : монографія / Л.М. Тарасюк. - Суми : Вид-во "Мрія-1", 2014. - 608 с.

2. Статистичний щорічник України за 2013 р. / за ред. О.Г. Осауленка. - К. : ТОВ "Вид-во Консультант", 2014. - $531 \mathrm{c}$.

3. Репин В.В. Бизнес-процессы компании: построение, анализ, регламентация / В.В. Репин. - М. : Изд-во РИА "Стандарты и качество", 2007. - 240 с.

4 . вомаренко В С. Теорія та прекика моделювання бізнес-пронесів : монографія / В.С. Пономаренко, С.В. Мінухін, С.В. Знахур. - Харків : Вид-во ХНЕУ, 2013. - 244 с.

5. Командровська В.С. Бізнес-процеси підприємства: сутність та методи вдосконалення / В.С. Командровська, О.Ю. Морозенко. [Електронний ресурс]. - Доступний 3 http://www.nbuv. gov.ua/portal/soc_gum/ppei/2011_30/Moroz.pdf.

Теребух А.А., Ильницкая-Гикавчук Г.Я., Макар О.П. Совершенствование управления бизнес-процессами на предприятиях Украины

Рассмотрены и проанализированы сущность управления на основе бизнес-процессов, преимущества предприятий от его внедрения. Установлено, что современное состояние экономики характеризуется низкой инновационной активностью, поэтому необходимо перепроектировать бизнес-процессы на предприятиях. Выделены следующие виды бизнес-процессов: основные, обеспечительные, управления и развития. Проведена классификация методов совершенствования управления бизнес-процессами, в частности выделены следующие методы: реинжиниринг, перепроектирования, бенчмар кинг, анализ рабочих ячеек, идеализация.

Ключевые слова: бизнес-процесс, управление, предприятие, узкое место, реинжиниринг, перепроектирование, бенчмаркинг. 
Terebuh A.A., Ilnytska-Hykavchuk G.Ya., Makar O.P. Improving Business

\section{Process Management in Ukraine}

The essence of management based on business processes and enterprise benefits from its implementation are considered and analyzed. The current state of the economy is found to be characterized by low innovation activity, so it is necessary to redesign business processes at enterprises. The authors highlight the following types of business processes: basic, interim, management and development. The classification of methods for improving the management of business processes is done, such as re-engineering, benchmarking, analysis of business centres, idealization.

Keywords: business process, management, enterprise, bottleneck, reengineering, redesign, benchmarking.

\section{УДК 330.1+338.1}

Проф. І.В. Грабинська, канд. екон. наукЛьвівський НУ ім. Івана Франка

\section{ВНЕСОК ВОЛОДИМИРА ТИМОШЕНКА У РОЗВИТОК АГРАРНОЇ \\ ТЕОРІЇ ЕКОНОМІЧНИХ КОЛИВАНЬ}

3'ясовано наявні підходи та труднощі класифікації теорій економічних коливань, а також місце аграрної теорії економічних циклів у загальній архітектурі макроекономічної науки. Досліджено історичні умови зародження, напрямки розвитку аграрної теорії ділових циклів та ії вплив на розвиток сучасної макроекономічної теорії. Американський економіст українського походження В. Тимошенко зробив помітний внесок у розвиток цієї теорії. Проаналізовано основні положення теоретичної концепції В. Тимошенка. На основі проведених розрахунків "індексу Тимошенка" для економіки України у 2000-2014 pp., зроблено висновок про те, що основні положення аграрної теорії ділоу 2000-2014 рр., зроблено висновок про те, що основн положня аграрної теоріі ділових циклів можуть бути використані у прогнозуванні та аналізі причин і наслідків коливань ділової активності у країнах із великою питомою вагою сільського господарства у галузевій структурі. За таких умов коливання обсягів сільськогосподарського виробництва можуть впливати на виробничу функцію, рівень доходів, обсяг інвестицій, а отже - і на економічне зростання.

Ключові слова: конвенціоналізм, ортодоксальні теорії, парадигма, економічні коливання, ділова активність, макроекономічна нестабільність, екстернальні теорії, цикл врожайності, "індекс Тимошенка".

Вступ. Об'єктивні процеси, що відбуваються як у глобальній економіці, так і в господарській системі України, створюють передумови коливань ділово активності. Це явище простежується у ринковій економіці з першої чверті XIX ст., і відтоді економісти намагаються його пояснити. Встановленню сучасних уявлень про природу циклів і криз передували роботи не одного покоління економістів. Нагромаджений вагомий теоретичний доробок у цій галузі за останні два століття сприяв тому, що сьогодні проблема циклів і криз належить до центральних в економічній теорії та становить важливу складову частину світової історії економічної думки.

Попередні дослідження та публікації. Серед дослідників коливань ділової активності у XIX ст. були: Ж.Б. Сей, Д. Рікардо, Дж. Вільсон, В. Беджгот, У.С. Джевонс, К. Маркс, К. Жуглар, Ж. де Сісмонді, К. Родбертус, Т. Мальтус, Дж. Міль, С. Дюрінг та ін. Наприкінці XIX ст. теорію коливань ділової активності розвивав М.I. Туган-Барановський, у XX ст. - Є. Слуцький, А. Шпітгоф, Дж. Кейнс, Й. Шумпетер, Н. Кондратьєв, І. Фішер, Дж. Кларк, А. Пігу, Р. Гоут- pi, Ф. фон Гайєк, Е. Ліндаль, Дж. Робертсон, Р. Лукас, Г. Манків, Ф. Кідленд, Е. Прескот та ін. Критичний аналіз теорій ділових циклів здійснено у роботах Ю. Бажала, А. Гальчинського, Г. Кліміної, Л. Тведе, В. Тимошенка, Ф. Клейна, Е. Боема, Т. Гала та ін.

Мета дослідження - простежити еволюцію поглядів представників різноманітних шкіл і напрямів світової економічної думки на аграрні теорії коливань ділової активності та визначити вплив наукового доробку В. Тимошенка на розвиток цих теорій.

Виклад основного матеріалу. У сучасній економічній науці нараховується десятки теорій, які намагаються пояснити причини коливань ділової активності і на цій основі визначити дієві заходи подолання їх негативних наслідків. У сучасній літературі наведено різноманітні підходи до класифікації такої широкої палітри теорій. Насправді класифікація наявних теорій виявилась не такою простою справою, оскільки багато 3 них мають еклектичний характер і поєднують різні чинники та підходи.

Історики економічної науки почасти трактують розвиток науки з позицій конвенціоналізму, і для класифікації економічних теорій бізнес-циклу застосовують парадигмальний підхід. Так, наприклад, економічні теорії бізнес-циклу поділяють на ортодоксальні та гетеродоксальні. Перші пов'язують із неокласичною, маржиналістською, новокласичною парадигмою, яка стала провідною теоретичною конструкцією у сучасній економічній науці. Одночасно виділяють гетеродоксальні, до яких відносять марксистську, неомарксистську, інституційну, посткейнсіанську теорії. Оскільки аналіз коливань ділової активності передбачає дослідження минулого, то гетеродоксальна економічна теорія дає певну методологічну основу та інструменти для цього.

Однак економісти дедалі частіше схиляються до думки, що існуючі теорії економічних коливань можна поділити на дві групи - екстернальні та інтернальні. Екстернальні теорії шукають основні причини економічних коливань у чинниках, які лежать за межами економічної системи [5, с. 289].

Так, Т. Гал зазначає, що до інтернальних теорій належать ті, які пояснюють економічні коливання як самогенеровані явища, тобто цикли повторюються періодично, завдяки впливу ендогенних факторів економічної системи, і визначаються показником сукупної економічної активності. Низка теорій ділових циклів не можна однозначно віднести до категорії інтернальних чи екстернальних. Наприклад, інтернальні теорії можуть вимагати дії екзогенного чинника, який відновить (встановить, допоможе відновити) самогенеруючі функції економічної системи і сприятиме іï поверненню до рівноваги. На думку Т. Гала, більшість теорій містять як ендогенні, так і екзогенні елементи. Для того, щоб класифікувати такі теорії, потрібно проаналізувати, які елементи (екзогенні чи ендогенні) є домінуючими [9, p. 29].

Детальніше пояснення екстернальних теорій дають К. Даутен, Л. Валентіне [8, p. 98]. Вони стверджують, що екзогенні теорії ділових циклів - це такі теорії, в яких циклічна природа ділової активності пояснена циклічною поведінкою певних зовнішніх факторів. Водночас логічно виникає запитання: які явища та коливання величини яких змінних належать до екзогенних? Ми може- 